\title{
Effect of peptide distribution on the fractionation of whey protein hydrolysates by nanofiltration membranes
}

\author{
Yves Pouliot*, Sylvie F. Gauthier, Josée L'HeureuX \\ Département des sciences des aliments et de nutrition, \\ Centre de recherche STELA, \\ Université Laval, Québec, Canada, G1K 7P4A
}

\begin{abstract}
The fractionation of tryptic and chymotryptic hydrolysates of whey proteins by nanofiltration (NF) membranes has been investigated. Enzymatic hydrolysates were prepared by tryptic (TH) or chymotryptic $(\mathrm{CH})$ hydrolysis of a commercial whey protein isolate followed by UF-treatment using a $10000 \mathrm{~g} \cdot \mathrm{mol}^{-1} \mathrm{MWCO}$ in order to remove the enzyme and non-hydrolyzed material from the reaction mixture. Both hydrolysates were further fractionated using a SG13 (Osmonics) cellulose acetate NF membrane with a molecular weight cut-off (MWCO) of $2500 \mathrm{~g} \cdot \mathrm{mol}^{-1}$. A detailed examination of the peptide separation revealed that, for both $\mathrm{TH}$ and $\mathrm{CH}$, the negatively charged peptides were in lower proportion in the permeates whereas the opposite trend was observed for neutral and positively charged peptides. However, the fractionation of TH lead to a better separation between charged fragments than that of $\mathrm{CH}$. This can be explained by the broader range of peptide characteristics (mass, charge) in $\mathrm{CH}$ as a result of the broader specificity of chymotrypsin.
\end{abstract}

nanofiltration / peptide / enzyme specificity / membrane selectivity / fractionation

\section{INTRODUCTION}

Membrane fractionation of milk protein enzymatic hydrolysates can lead to peptide mixtures having improved functionality [3, 14], lower salt content [16], or simply modified peptide contents $[4,11]$. Nanofiltra- tion (NF) membranes have been used to separate model systems of amino acids [5, 7, 12, 13], peptides [4] and enzymatic hydrolysates from whey proteins [11]. The existing literature suggests that mixtures of peptides can be fractionated with NF membranes and that the separation mechanism is based on a

\footnotetext{
* Correspondence and reprints. Yves.Pouliot@aln.ulaval.ca
} 
molecular sieve effect and/or on a charge effect depending on the membrane type and the feed phase composition.

Martin-Orue et al. [8] recently proposed a general mechanism for the separation of amino acid and peptide mixtures. The authors demonstrated that charge is the most important criterion for the NF-separation of solutes having similar molecular weight. The transmission of peptides across NFmembranes would result from the combination of a convective flow $\left(\mathrm{J}_{\mathrm{c}}\right)$ resulting in an excess of charged specied (co- and counter-ions) towards the membrane which in turn would give rise to an opposing electromigrative flow $\left(\mathrm{J}_{\mathrm{e}}\right)$ of counter-ions. Hence, the electrophoretic mobility of peptides and ionic species was proposed as criteria for fractionation. A new basic concept taking into account the unequal distribution of counter and coionic side-chain residues in the sequence of peptides was also introduced.

Our earlier work on the fractionation of whey protein tryptic hydrolysates using NF membranes [11] has also revealed the possible occurrence of specific rejection phenomena involving negatively charged peptides by NF membranes. The separation performance of 5 polymeric (polyamide and cellulose acetate) NF-membrane materials was investigated. It was observed that $\mathrm{pH}$ increase from 5 to 9 not only raised the flux and nitrogen transmission values but also decreased the tendency to fouling. Adding $\mathrm{NaCl}$ also increased permeability but increased the tendency to fouling of the membranes. A detailed examination of the peptide separation revealed that negatively charged peptides were in lower proportion in the permeates whereas the opposite trend was observed for neutral and positively charged peptides. Our observations on the fractionation of whey protein tryptic hydrolysates were in good agreement with the data from Martin-Orue et al. [8] which were obtained in model peptidic solutions.

The present study was led in order to investigate the effect of peptide distribution in whey protein enzymatic hydrolysates on the fractionation profile by NF-membranes. Proteases having different substrate specificity, namely trypsin, which cleaves at the C-terminal end of Arg and Lys, and chymotrypsin which requires an aromatic or bulky non-polar side chain (Phe, Leu, Tyr, Trp) on the carboxyl side of the scissile bond $[9,10]$ were used in order to generate two different hydrolysates. The fractionation of the hydrolysates was performed at $\mathrm{pH}$ 9.0, using a $2500 \mathrm{~g} \cdot \mathrm{mol}^{-1} \mathrm{MWCO}$ cellulosic NFmembrane as previously investigated [11].

\section{MATERIALS AND METHODS}

\subsection{Preparation of the hydrolysate}

The preparation of tryptic hydrolysates was performed as previously described in Pouliot et al. [11] from a $10 \%$ (w/v) solution of commercial whey protein isolate (Bipro, Davisco Foods International Inc., Le Sueur, MN, USA) and using commercial trypsin (PTN-6.0S, Novo Nordisk, Copenhague, DE). The hydrolysis reaction was stopped at a degree of hydrolysis (DH) of $5.6 \%$, as determined by $\mathrm{pH}$-stat technique [1]. At this DH value, the enzyme and non-hydrolyzed proteins were removed by ultrafiltration (UF) using a $10000 \mathrm{~g} \cdot \mathrm{mol}^{-1} \mathrm{MWCO}$ hollow fiber polysulfone membrane (PM10, Romicon Inc., Woburn, MA, USA). The chymotryptic hydrolysate $(\mathrm{CH})$ was prepared using an overall procedure similar to that used for $\mathrm{TH}$, except that commercial chymotrypsin (Chymotrypsin $800 \mathrm{~S}$ oral grade, Novo Nordisk, Copenhague, DE) was used and that a final DH of $7.2 \%$ was obtained.

\subsection{Membrane separation}

The NF-membrane material was composed of cellulose acetate and its MWCO was estimated at $2500 \mathrm{~g} \cdot \mathrm{mol}^{-1}$ (SG13, specification provided by Osmonics). The membranes coupons with an area of $1.55 \times 10^{-2} \mathrm{~m}^{2}$ were soaked overnight in $18 \mathrm{M} \Omega$ purified 
water (Modulab Analytical, Fischer Scientific, Montreal, Qc, Canada). Every permeation experiment was performed with three different new membranes which were conditioned according to Wijers et al. [16]. Before the membrane experiments, a feed phase was prepared by dissolving enzymatic hydrolysates $(\mathrm{TH}, \mathrm{CH})$ in purified water to a protein concentration of $1.0 \% \mathrm{w} / \mathrm{v}$. The $\mathrm{pH}$ was adjusted to $9.0 \mathrm{using}$ a $1.0 \mathrm{~mol} \cdot \mathrm{L}^{-1}$ sodium hydroxide solution (volumetric solution 1 N, Anachemia Canada, Montreal, Qc, Canada).

The filtration experiments were performed in a cross-flow SEPA CF cell (Osmonics, Minnetonka, MN, USA). The temperature of the module and phases was $40{ }^{\circ} \mathrm{C}$. The flow velocity of the feed phase was $0.33 \mathrm{~m} \cdot \mathrm{s}^{-1}$ and the transmembrane pressure $5 \times 10^{5} \mathrm{~N} \cdot \mathrm{m}^{-2}$. The experimental procedure previously described by Wijers et al. [16] was followed.

\subsection{Analytical methods}

The following analytical methods were used for the characterization of the whey protein isolate, $\mathrm{TH}$ and $\mathrm{CH}$ : Kjeldahl method [6] for total nitrogen, an enzymatic lactose/D-glucose bioassay (BoehringerMannheim GmbH, Germany) for lactose, Mojonnier method for fat content, and incineration at $550{ }^{\circ} \mathrm{C}$ for ash determinations.

Capillary electrophoresis (model ${ }^{3 \mathrm{D}} \mathrm{CE}$, Hewlett Packard, Kirkland, Qc, Canada) has been used to analyze the ion concentrations. A silica capillary was used with an inner diameter of $50 \mu \mathrm{m}$ and a length of $72 \mathrm{~cm}$. For the analysis of the anions (chloride) a buffer of pyromellitic acid, sodium hydroxide, hexamethonium hydroxide and triethanolamine was used (Dionnex, Sunnyvale, CA, USA). The buffer for the cation analysis (potassium, sodium, calcium, magnesium) contained sulfuric acid, 18-crown and formic acid. Before injection the samples were filtered through a filter (polyvinylidene fluoride) of $0.2 \mu \mathrm{m}$ (Acrodisc ${ }^{\circledR}$
LC13 PVDF, Gelman Sciences, Ann Arbor, MI, USA). The samples were injected during $4 \mathrm{~s}$ at 50 mbar. The detection was at $350 \mathrm{~nm}$ for the anions and at $340 \mathrm{~nm}$ for the cations.

All high performance liquid chromatography (HPLC) analyses were performed using a system consisting of an injector (Rheodyne Model 7725i, Cotati, CA, USA), a pump (Waters Model 600E, Milford, MA, USA) and a Waters 486 UV detector. Data were collected and treated using the chromatographic software Millennium (Waters).

The determination of peptidic composition was performed on a Nova-Pak $\mathrm{C}_{18}$ column (3.9 i.d. $\times 150 \mathrm{~mm}$, Waters, Milford, MA, USA) using the following conditions: flow rate, $1 \mathrm{~mL} \cdot \mathrm{min}^{-1}$; column temperature, $39{ }^{\circ} \mathrm{C}$; solvent A, $0.11 \%$ (v/v) trifluoroacetic acid (TFA) in water; solvent B, 60\% (v/v) acetonitrile and $40 \%(\mathrm{v} / \mathrm{v})$ water and $0.1 \%$ (v/v) TFA. Elution was obtained with a linear gradient from 0 to $60 \%$ of solvent B in $30 \mathrm{~min}$. Absorbance was measured at $220 \mathrm{~nm}$.

The collected fractions were dried in a Speed-Vac concentrator (Savant Instruments, Farmingdale, NY, USA) and stored for peptide identification. After acid hydrolysis under vacuum in the presence of $6 \mathrm{~mol} \cdot \mathrm{L}^{-1} \mathrm{HCl}$ for $24 \mathrm{~h}$ at $110^{\circ} \mathrm{C}$ in a PicoTag Station (Waters, Milford, MA, USA), amino acids were derivatized with PITC according to the method of Bidlingmeyer et al. [2]. The identification of peptides was performed according to results of Pico-Tag amino acids analysis as described earlier [16].

\section{RESULTS AND DISCUSSION}

\subsection{Compositional characteristics of $\mathrm{TH}$ and $\mathrm{CH}$}

Table I reports the compositional data of the whey protein isolate (WPI) and of the hydrolysates $\mathrm{TH}$ and $\mathrm{CH}$ obtained following 
Table I. Overall composition of tryptic (TH) and chymotryptic $(\mathrm{CH})$ hydrolysates in comparison to that of whey protein isolate.

\begin{tabular}{lrrr}
\hline & Whey protein isolate & $\mathrm{TH}$ & $\mathrm{CH}$ \\
\hline Protein $(\% \mathrm{w} / \mathrm{w})$ & 93.3 & 81.2 & 93.3 \\
Fat $(\% \mathrm{w} / \mathrm{w})$ & 0.2 & $\mathrm{nd}$ & $\mathrm{nd}$ \\
Lactose $(\% \mathrm{w} / \mathrm{w})$ & 0.1 & $\mathrm{nd}$ & $\mathrm{nd}$ \\
Ash $(\% \mathrm{w} / \mathrm{w})$ & 2.0 & 6.2 & 6.1 \\
Minerals $\left(\mathrm{mg} \cdot 100 \mathrm{~g}^{-1}\right)$ & & & \\
$\quad$ Calcium $(\mathrm{Ca})$ & 74 & 380 & 209 \\
Magnesium $(\mathrm{Mg})$ & 11 & 2 & 15 \\
$\quad$ Sodium $(\mathrm{Na})$ & 567 & 1991 & 2507 \\
Potassium $(\mathrm{K})$ & 90 & 175 & 113 \\
Chloride $(\mathrm{Cl})$ & 5 & 1394 & 918 \\
\hline
\end{tabular}

nd $=$ not determined

enzymatic hydrolysis and UF. Both TH and $\mathrm{CH}$ mainly differed from WPI with respect to their higher ash content (6.1-6.2\% vs. $2.0 \%$ ) which was also reflected by the higher $\mathrm{Ca}, \mathrm{Na}$ and $\mathrm{Cl}$ contents in $\mathrm{TH}$ and $\mathrm{CH}$, in comparison to WPI. This higher salt content can be explained by the fact that $\mathrm{CaCl}_{2}$ was added to the reaction mixtures prior to enzymatic hydrolysis in order to stabilize trypsin and chymotrypsin, and also, because the hydrolysis was performed using $\mathrm{pH}$-stat technique [1] which involves the addition of $\mathrm{NaOH}$. The higher chloride content of $\mathrm{TH}$ and $\mathrm{CH}$ is however unexpected and cannot be explained only by $\mathrm{CaCl}_{2}$ additions. In fact, it may be a result of contamination of the reaction mixtures by chlorinated cleaning and/or storage solutions remaining in the UF-membrane between trials. The overall composition of $\mathrm{TH}$ and $\mathrm{CH}$ only differed with respect to $\mathrm{Na}$ content which were higher in $\mathrm{CH}$. A higher $\mathrm{DH}$ value (7.2 vs. $5.6 \%$ ) was reached during chymotryptic hydrolysis and so, a higher amount of $\mathrm{NaOH}$ was required in order to maintain $\mathrm{pH}$ constant.

\subsection{Transmission of peptides}

Although over 23 different peptides from $\beta-\mathrm{gg}$ were detected in both $\mathrm{TH}$ and $\mathrm{CH}$, only those present at a concentration higher than $2.5 \%$ in the hydrolysate, retentate or permeate were further investigated and listed in Tables II and III. It can be noticed that the peptides identified from $\mathrm{CH}$ were in a greater number than those from TH (19 vs. 12 sequences) but also the content of each peptide was lower, so that even the retentates needed to be analyzed in order to detect significant amount of a given peptide (e.g. Tab. III, f8-14).

The transmission of peptides from $\mathrm{TH}$ across NF-membrane was in accordance with the data already reported in Pouliot [11] and showed that negatively charged peptides such as f25-40 or f84-91 were in a lower proportion in the permeate, whereas positively charged and neutral peptides such as $\mathrm{f} 1-8$ or $\mathrm{f} 15-20$ were in greater proportion in the permeate. Such trend could not be observed upon NF fractionation of $\mathrm{CH}$. Due to the generally lower contents in each peptide sequence, data were from $\mathrm{CH}$, retentate or permeate were often missing and the transmission of peptides would not be in accordance with the sign of charge. As for example, peptide f33-39 and which is negatively charged at $\mathrm{pH} 9$ was found in greater concentration in the permeate. NF-fractionation of $\mathrm{CH}$ thus showed discrepancies compared to that of TH. Table IV illustrates 
Table II. Physicochemical characteristics and content in peptides from $\beta$-lactoglobulin determined in tryptic hydrolysate (TH) and in NF-permeate.

\begin{tabular}{lccrcc}
\hline Peptide & $\begin{array}{c}\text { Theoretical } \\
\text { mass } \\
\left(\mathrm{g} \cdot \mathrm{mol}^{-1}\right)^{(1)}\end{array}$ & $\begin{array}{c}\text { Isoelectric } \\
\text { point }^{(1)}\end{array}$ & $\begin{array}{c}\text { Charge at } \\
\mathrm{pH} \mathrm{9(2)}\end{array}$ & \multicolumn{2}{c}{$\begin{array}{c}\text { Estimated content } \\
(\%)\end{array}$} \\
\cline { 5 - 6 } & & & & $\mathrm{TH}$ & NF-Permeate \\
\hline $\mathrm{f} 1-8$ & 933 & 8.75 & +1 & 4.3 & 6.5 \\
$\mathrm{f} 15-20$ & 696 & 5.49 & 0 & 13.0 & 23.5 \\
$\mathrm{f} 25-40$ & 1628 & 4.21 & -1 & 5.0 & 4.2 \\
$\mathrm{f} 61-69^{(5)}+149-162$ & 2721 & 4.48 & -3 & 3.2 & $*(4)$ \\
$\mathrm{f} 61-70^{(5)}+149-162$ & 2849 & 4.91 & -2 & 4.1 & $*$ \\
$\mathrm{f} 71-75$ & 573 & 6.00 & 0 & 3.5 & 4.7 \\
$\mathrm{f} 76-82$ & 775 & 8.41 & +1 & $*$ & 3.0 \\
$\mathrm{f} 78-82$ & 546 & 5.52 & 0 & $*$ & 3.5 \\
$\mathrm{f} 84-91$ & 916 & 4.37 & -1 & 3.8 & 3.0 \\
$\mathrm{f} 125-135$ & 1245 & 3.83 & -4 & 3.8 & $*$ \\
$\mathrm{f} 136-138$ & 408 & 5.84 & 0 & 3.0 & 4.8 \\
$\mathrm{f} 142-148$ & 837 & 9.80 & +1 & 4.3 & 7.4 \\
\hline
\end{tabular}

(1) Calculated with the aid of ExPASy Molecular Biology Server [15].

(2) Assuming N-terminal and C-terminal are in ionized form at $\mathrm{pH} 9.0$.

(3) Concentrations were estimated from peak areas in the RP-HPLC chromatograms $\left(\mathrm{C}_{18}\right)$; only the values $>2.5 \%$ were reported.

(4) Symbol (*) refers to a concentration $<2.5 \%$.

(5) Peptides linked by a disulfide bond.

these differences by allowing the comparison of NF-permeation of 4 peptidic sequences which were present in both hydrolysates, namely, f15-20, f76-82, f78-82 and 84-91. The relative concentration values $\left(\mathrm{C}_{\mathrm{p}} / \mathrm{TH}\right.$ and $\left.\mathrm{C}_{\mathrm{p}} / \mathrm{CH}\right)$ were markedly different for f76-82 and f78-82 upon their NF in $\mathrm{TH}$ and $\mathrm{CH}$. This observation is unexpected and difficult to explain in the light of the existing theory of mechanism [8].

The distribution of theoretical molecular mass and isoelectric point (PI) of peptides in $\mathrm{TH}$ and $\mathrm{CH}$ (including those $<2.5 \%$ which are not reported in Tabs. II and III) is depicted in Figure 1. The distribution of peptides in $\mathrm{CH}$ is characterized by a greater number of peptides of molecular mass below $1000 \mathrm{~g} \cdot \mathrm{mol}^{-1}$ in comparison to TH (17 vs.
10) although the range of PI values are equivalent for $\mathrm{TH}$ and $\mathrm{CH}$. This difference in peptide distribution may in fact complicate NF-fractionation since a greater number of short peptides having different charge characteristics, and eventually different electrophoretic mobilities, may affect the intensity of both the convective and electromigrative fluxes across the membrane. As a consequence of this broader distribution of peptide characteristics, a poorer separation between co- and counter-ions is obtained. Differences in the ionic distribution of $\mathrm{TH}$ and $\mathrm{CH}$ may also explain the poorer separation observed during $\mathrm{NF}$ of $\mathrm{CH}$. Complete analytical data of all anions and cations present in $\mathrm{TH}$ and $\mathrm{CH}$ should however be considered before reaching any conclusion. 
Table III. Physicochemical characteristics and content in peptides from $\beta$-lactoglobulin determined in chymotryptic hydrolysate $(\mathrm{CH})$, in NF-retentate and in NF-permeate.

\begin{tabular}{|c|c|c|c|c|c|c|}
\hline \multirow[t]{2}{*}{ Peptide } & \multirow{2}{*}{$\begin{array}{l}\text { Theoretical } \\
\text { mass } \\
\left(\mathrm{g} \cdot \mathrm{mol}^{-1}\right)^{(1)}\end{array}$} & \multirow[t]{2}{*}{$\begin{array}{l}\text { Isoelectric } \\
\text { point }^{(1)}\end{array}$} & \multirow[t]{2}{*}{$\begin{array}{c}\text { Charge at } \\
\mathrm{pH} 9^{(2)}\end{array}$} & \multicolumn{3}{|c|}{$\begin{array}{l}\text { Estimated content } \mathrm{t}^{(3)} \\
(\%)\end{array}$} \\
\hline & & & & $\mathrm{TH}$ & NF-Ret & NF-Perm \\
\hline f8-14 & 801 & 8.59 & +1 & $*(4)$ & 3.7 & $*$ \\
\hline f15-19 & 533 & 5.49 & 0 & 8.6 & 7.7 & 12.0 \\
\hline $\mathrm{f} 15-20$ & 696 & 5.49 & 0 & 3.5 & 3.3 & 7.0 \\
\hline f33-39 & 701 & 3.80 & -1 & 6.1 & 4.7 & 8.0 \\
\hline $\mathrm{f} 41-42$ & 280 & 5.49 & 0 & $*$ & $*$ & 3.7 \\
\hline $\mathrm{f} 41-60$ & 2314 & 4.25 & -3 & $*$ & 3.3 & * \\
\hline $\mathrm{f} 70-75$ & 701 & 8.59 & +1 & $*$ & $*$ & 4.0 \\
\hline f76-82 & 775 & 8.41 & +1 & 4.9 & $*$ & 4.9 \\
\hline f78-82 & 546 & 5.52 & 0 & 9.5 & 2.6 & $*$ \\
\hline f84-91 & 916 & 4.37 & -1 & 2.9 & 3.4 & $*$ \\
\hline f94-101 & 981 & 5.93 & 0 & * & $*$ & 4.9 \\
\hline f96-99 & 512 & 3.56 & -2 & 2.6 & $*$ & $*$ \\
\hline f100-103 & 551 & 9.70 & +2 & $*$ & $*$ & 2.9 \\
\hline f103-105 & 392 & 5.52 & 0 & $*$ & $*$ & 3.4 \\
\hline f125-135 & 1245 & 3.83 & -4 & $*$ & 4.4 & $*$ \\
\hline f125-136 & 1392 & 3.83 & -4 & $*$ & 4.5 & $*$ \\
\hline f125-138 & 1636 & 4.02 & -4 & $*$ & $*$ & $*$ \\
\hline f142-145 & 431 & 5.57 & 0 & 2.8 & 2.5 & 8.0 \\
\hline f146-148 & 425 & 9.76 & +1 & * & * & 3.4 \\
\hline
\end{tabular}

(1) Calculated with the aid of ExPASy Molecular Biology Server [15].

(2) Assumming N-terminal and C-terminal are in ionized form at $\mathrm{pH} 9.0$.

(3) Concentrations were estimated from peak areas in the RP-HPLC chromatograms $\left(\mathrm{C}_{18}\right)$; only the values $>2.5 \%$ were reported.

(4) Symbol $(*)$ refers to a concentration $<2.5 \%$.

Table IV. Sequence and relative concentration values of peptides found upon nanofiltration of TH and $\mathrm{CH}$.

\begin{tabular}{|c|c|c|c|c|}
\hline \multirow[t]{2}{*}{ Peptide } & \multirow[t]{2}{*}{ Sequence } & \multirow{2}{*}{$\begin{array}{c}\text { Charge } \\
\text { pH } 9\end{array}$} & \multicolumn{2}{|c|}{ Relative concentration } \\
\hline & & & $\mathrm{C}_{\mathrm{p}} / \mathrm{TH}$ & $\mathrm{C}_{\mathrm{p}} / \mathrm{CH}$ \\
\hline$\beta-\lg 15-20$ & Val-Ala-Gly-Thr-Trp-Tyr & 0 & 1.8 & 2.0 \\
\hline$\beta-\lg 76-82$ & Thr-Lys ${ }^{+}$-Ile-Pro-Ala-Val-Phe & +1 & 1.5 & $<0.9$ \\
\hline$\beta-\lg 78-82$ & Ile-Pro-Ala-Val-Phe & 0 & 1.8 & $<0.3$ \\
\hline$\beta-\lg 84-91$ & Ile-Asp-Ala-Leu-Asn-Glu-Asn-Lys ${ }^{+}$ & -1 & 0.8 & 0.9 \\
\hline
\end{tabular}



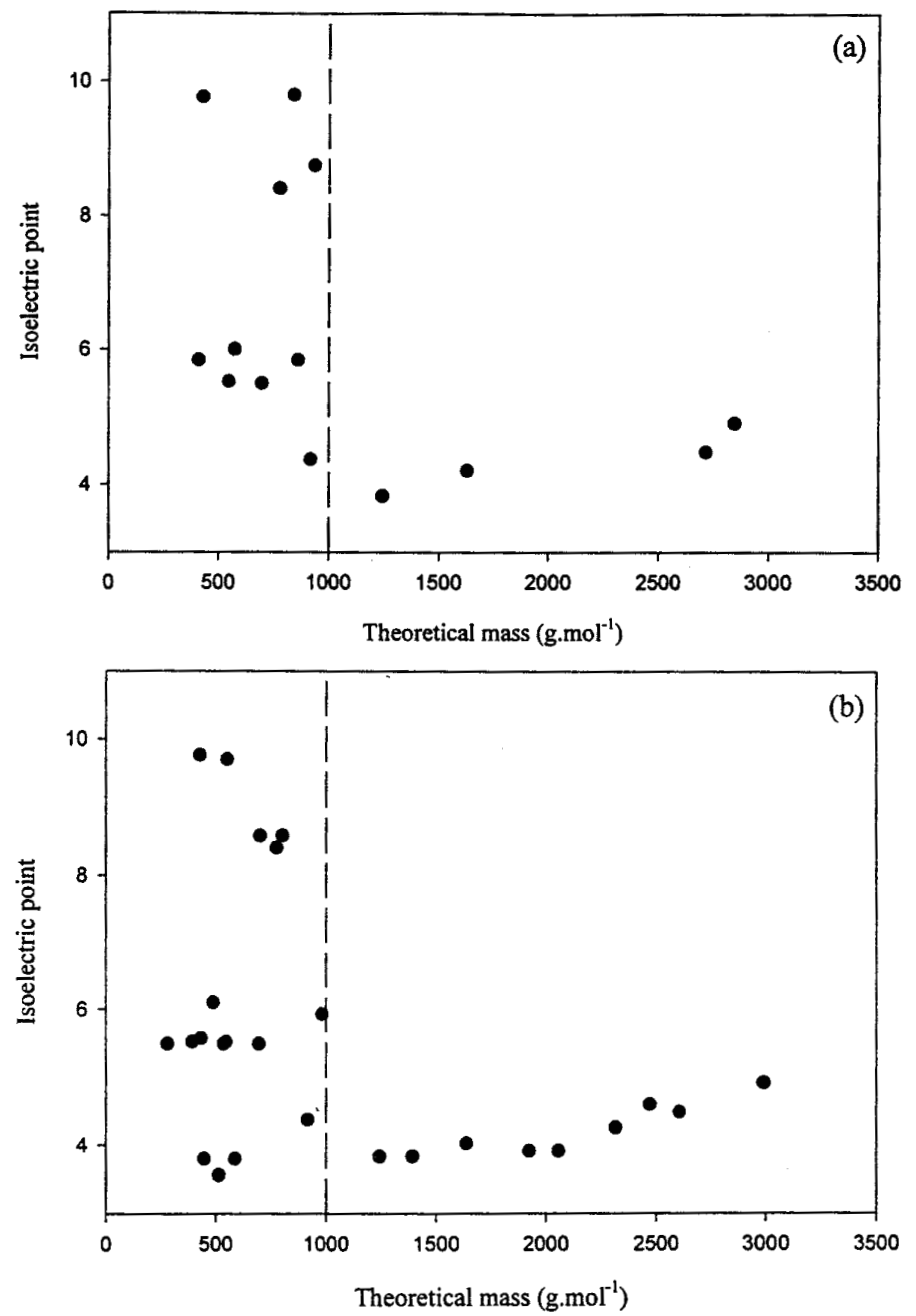

Figure 1. Distribution between theoretical mass $\left(\mathrm{g} \cdot \mathrm{mol}^{-1}\right)$ and isoelectric point (PI) of peptides identified in $\mathrm{TH}$ (a) and $\mathrm{CH}(\mathrm{b})$.

\section{CONCLUSION}

This work evidences the difficulty of separating complex systems such as whey protein hydrolysates. It underlines the critical impact of enzyme specificity which in turns determines the physicochemical character- istics of the peptides in the hydrolysate. The mineral composition of the hydrolysates should also be taken into account. More work is needed in order to find technological alternatives or physicochemical treatments in order to further amplify charge effects and obtain a more efficient separation between peptidic species. 


\section{ACKNOWLEDGMENTS}

This work was supported by a grant from the Natural Sciences and Engineering Research Council of Canada (NSERC).

\section{REFERENCES}

[1] Adler-Nissen J., Enzymic hydrolysis of food proteins, Process Biochem. 12 (1977) 18-24.

[2] Bidlingmeyer B.A., Coehn S.A., Tarvin T.L., Rapid analysis of amino acids using precolumn derivatization, J. Chromatogr. 336 (1984) 93-104.

[3] Chobert J.M., Bertrand-Harb C., Nicolas M.G., Solubility and emulsifying properties of caseins and whey proteins modified enzymatically by trypsin, J. Agric. Food Chem. 36 (1988) 883-892.

[4] Garem A., Daufin G., Maubois J.L., Chaufer B., Léonil J., Ionic interactions in nanofiltration of $\beta$-casein peptides, Biotechnol. Bioeng. 57 (1998) 109-117.

[5] Garem A., Léonil J., Daufin G., Maubois J.-L., Nanofiltration d'acides aminés sur membranes organiques : influence des paramètres physicochimiques et de la pression transmembranaire sur la sélectivité, Lait 76 (1996) 267-281.

[6] IDF Provisional Standard 20B, Determination of nitrogen content, International Dairy Federation, Brussels, Belgium, 1986.

[7] Kimura S., Tamano A., Separation of aminoacids by charged ultrafiltration membranes. Membranes and membrane processes, in: Membranes and membrane processes, Drioli E., Nahagaki M. (Eds.), Plenum Press, New York, 1986, pp. 191-197.
[8] Martin-Orue C., Bouhallab S., Garem A., Nanofiltration of amino acid and peptide solutions: mechanisms of separation, J. Membrane Sci. 142 (1998) 225-233.

[9] Pouliot Y., Gauthier S.F., Bard C., Fractionation of casein hydrolysates using polysulfone ultrafiltration hollow fiber membranes, J. Membrane Sci. 80 (1993) 257-264.

[10] Pouliot Y., Gauthier S.F., Bard C., Skimmilk solids as substrate for the preparation of casein enzymatic hydrolysates, J. Food Sci. 60 (1995) 111-116.

[11] Pouliot Y., Wijers M.C., Gauthier, S.F., Nadeau L., Fractionation of whey protein hydrolysates using charged UF/NF membranes, J. Membrane Sci. 158 (1999) 105-114.

[12] Timmer J.M.K., Speelmans M.P.J., van der Horst H.C., Separation of amino acids by nanofiltration and ultrafiltration membranes, Separ. Purif. Technol. 14 (1998) 133-144.

[13] Tsuru T., Shutou T., Nakao S.I., Kimura S., Peptide and amino acid separation with nanofiltration membranes, Separ. Sci. Technol. 29 (1994) 971-984.

[14] Turgeon S.L., Gauthier S.F., Whey peptide fractions obtained with a two-step ultrafiltration process: production and characterization, J. Food Sci. 55 (1990) 106-110, 157.

[15] Wilkins M.R., Gasteiger E., Bairoch A., Sanchez J.C., Williams K.L., Appel R.D., Horschstrasser D.F., Protein identification and analysis tools in the ExPASy Server, in: Link A.J. (Ed.), 2-D Proteome analysis protocols, Humana Press, New Jersey, USA, 1998.

[16] Wijers M.C., Pouliot Y., Gauthier S.F., Pouliot M., Nadeau L., Use of nanofiltration emebranes for the desalting of peptide fractions from whey protein enzymatic hydrolysates, Lait 78 (1998) 621-632. 